\title{
Effects of irradiance and copper on the activity of ascorbate oxidase in detached rice leaves
}

\author{
L.-M. CHEN and C.H. KAO
}

Department of Agronomy, National Taiwan University, Taipei 106, Taiwan, Republic of China

\begin{abstract}
The effects of copper on the activity of ascorbic acid oxidasc (AAO) in detached rice leaves under both light and dark conditions and in etiolated rice seedlings were investigated. $\mathrm{CuSO}_{4}$ increased $\mathrm{AAO}$ activity in detached rice leaves in both light and darkness, however, the induction in darkness was highter than in the light. In the absence of $\mathrm{CuSO}_{4}$, irradiance $\left(40 \mu \mathrm{mol} \mathrm{m} \mathrm{m}^{-2} \mathrm{~s}^{-1}\right)$ resulted in a higher activity of AAO in detached rice leaves than dark treatment. Both $\mathrm{CuSO}_{4}$ and $\mathrm{CuCl}_{2}$ increased $\mathrm{AAO}$ activity in detached rice leaves, indicating that AAO is activated by $\mathrm{Cu}$. Sulfate salts of $\mathrm{Mg}, \mathrm{Mn}, \mathrm{Zn}$ and $\mathrm{Fe}$ were ineffective in activating AAO in detached leaves. $\mathrm{CuSO}_{4}$ was also observed to increase AAO activity in the roots but not in shoots of etiolated rice seedlings.
\end{abstract}

Additional key words: Cu metalloenzyme, Oryza sativa.

\section{Introduction}

Ascorbic acid oxidase (AAO, EC 1.10.3.3) is a $\mathrm{Cu}$ metalloenzyme. It catalyzes the oxidation of ascorbic acid to dehydroascorbic acid. The definitive roles of AAO is not clear, although it has heen suggested that the enzyme may participate in a redox system involving ascorbic acid (Weis 1975) and in growth promotion (Lin and Varner 1991, Takahama and Oniki 1994).

It has been shown that AAO is induced hy adding conper into cell cultures from pumpkin (Esaka et al. 1988a, b, 1989, 1990, 1992), cucumber (Cho et al. 1989, Sekiya et al. 1990), or zucchini (Pitari et al. 1993). It is not known whether or not $\mathrm{Cu}$ activates $\Lambda \Lambda \mathrm{O}$ in other tissues, such as leaves and roots. In this study, detached rice leaves and etiolated rice seedlings were used to examine the effect of $\mathrm{Cu}$ on AAO activity.

Feceived 12 Mauclı 1999, accepted 1 July 1999.

Abbreviations: AAO - ascorbic acid oxidase; $\mathrm{CHI}$ - cycloheximide.

Acknowledgement: This work was supported by the National Science Council, the Republic of China, grant NSC 88-2313-B-002-066.

Fax: (+886) 22362 0879, e-mail: kaoch@cc.ntu.edu.tw 


\section{Materials and methods}

Fifty rice (Oryza sativa L. cv. Taichung Native 1) seedlings were planted on a stainless net floating on half-strength Johnson's modified nutrient solution ( $\mathrm{pH} \mathrm{4.2)}$ in a $500 \mathrm{~cm}^{3}$ beaker (Kao 1980). The nutrient solution was replaced every three days. Rice plants were grown for $12 \mathrm{~d}$ in a greenhouse under natural light and controlled temperature $30^{\circ} \mathrm{C}$ during the day and at $25^{\circ} \mathrm{C}$ at night. The apical $3 \mathrm{~cm}$ of the third leaf was used for the experiment. A group of 10 segments was floated in a Petri dish containing $10 \mathrm{~cm}^{3}$ distilled water or $\mathrm{CuSO}_{4}$ snhrtinns. Incubation was carried out at $27{ }^{\circ} \mathrm{C}$ in darkness or under irradiance $40 \mu \mathrm{mol} \mathrm{m} \mathrm{m}^{-2} \mathrm{~s}^{-1}$. For the etiolated seedlings, seeds were sterilized with $2.5 \%$ sodium hypochlorite for $15 \mathrm{~min}$ and washed extensively with distilled water These seeds were then germinated in Pctri dishes containing distilled water at $37^{\circ} \mathrm{C}$ under darkness. After $1 \mathrm{~d}$, uniformly germinated seeds were selected and transferred to a Petri dish containing 2 sheets of Whatman $\mathrm{No} /$ filter paper moistened with $10 \mathrm{~cm}^{3}$ distilled water or various concentrations of $\mathrm{CuSO}_{4}$ (pH 5.5). Each treatment was replicated 4 times. The germinated seeds were allowed to grow at $27{ }^{\circ} \mathrm{C}$ in darkness and additional $3 \mathrm{~cm}^{3}$ distilled water or treatment solutions was added to eacli Petri dish on day 3 of the growth. Roots or shoots of seedlings grown in darkness were harvested after $5 \mathrm{~d}$ to determine fresh mass (f. m.) and AAO activity.

Plant tissues (40 $\mathrm{mg}$ ) were homogenized in $4 \mathrm{~cm}^{3}$ of $50 \mathrm{mM}$ sodium phosphate buffer ( $\mathrm{pH} 6.8$ ) in a chilled mortar and pestle at $4{ }^{\circ} \mathrm{C}$. The homogenates were centrifuged at $17600 \mathrm{~g}$ for $20 \mathrm{~min}$, and the supernatants were used to assay AAO aclivily as described by Esaka et al. (1988a). AAO activity was assayed by a spectrophotometer (U-2000, Hitachi, Tokyo, Japan) by following the decrease in absorbance at wavelength $265 \mathrm{~nm}\left(\mathrm{~A}_{265}\right)$ of the reaction mixture containing $1 \mathrm{~cm}^{3}$ of $100 \mu \mathrm{MI}$ ascorbic acid, $1.8 \mathrm{~cm}^{3}$ of $50 \mathrm{mM}$ sodium phosphate buffer ( $\mathrm{pH} 6.8$ ) and $0.2 \mathrm{~cm}^{3}$ of enzyme extract. One unit $(\mathrm{U})$ of enzyme activity was defined as a decrease of $0.01 \mathrm{~A}_{265}$ per minute.

All experiments described here were repeated four times. Similar results and identical trends were obtained. The data reported here are from a single experiment.

\section{Results}

Under both light and dark, increasing concentrations of $\mathrm{CuSO}_{4}$ from 0.01 to $10 \mathrm{mM}$ progressively increased AAO activity in detached rice leaves (Table 1). After 24-h incubation in darkness, treatment with $10 \mathrm{mM} \mathrm{CuSO}_{4}$ increased AAO activity 3- to 4-fold. However, only about $50 \%$ increase in AAO activity in detached rice leaves treated with $10 \mathrm{mM} \mathrm{CuSO}_{4}$ for $24 \mathrm{~h}$ under light was found. These results indicated that $\mathrm{CuSO}_{4}$ was more effective in the dark than under light. In the absence of $\mathrm{CuSO}_{4}$, AAO activity did not change during the $24 \mathrm{~h}$ in the dark but increased under irradiance of $40 \mu \mathrm{mol} \mathrm{m} \mathrm{m}^{-2} \mathrm{~s}^{-1}$ which resulted in a higher activity of AAO under this irradiance than in the dark (Table 2). Increases in $\triangle \Lambda O$ activitics, as a consequence of $\mathrm{CuSO}_{4}$ treatment, were detected $4 \mathrm{~h}$ after that start of incubation in the dark 
(Table 2). When detached rice leaves were exposed to $\mathrm{CuSO}_{4}$, both in the dark and irradiated, AAO activities were found to increase up to $24 \mathrm{~h}$ (Table 2).

Table 1. Effects of various $\mathrm{CuSO}_{4}$ concentrations on the $\mathrm{AAO}$ activity in detached rice leaves under dark or light. Detached rice leaves were floated on solutions of $\mathrm{CuSO}_{4}$ at different concentrations for 24 h. Means $\pm \operatorname{SE}(n=4)$.

\begin{tabular}{lll}
\hline $\mathrm{CuSO}_{4}[\mathrm{mM}]$ & $\begin{array}{l}\text { AAO }\left[\mathrm{Ug} \mathrm{g}^{-1} \text { (f.m.) }\right. \\
\text { dark }\end{array}$ & \multicolumn{1}{l}{ light } \\
\hline 0 & $4.23 \pm 0.18$ & $12.17 \pm 0.09$ \\
0.01 & $6.58 \pm 0.87$ & $14.28 \pm 0.12$ \\
0.10 & $9.44 \pm 0.40$ & $15.00 \pm 1.28$ \\
1.00 & $11.87 \pm 0.12$ & $15.38 \pm 0.29$ \\
10.00 & $16.37 \pm 1.38$ & $18.58 \pm 0.58$ \\
\hline
\end{tabular}

Table 2. Time courses of AAO activity in detached rice leaves treated with $\mathrm{CuSO}_{4}(10 \mathrm{mM})$ or distilled water under dark or light. Means \pm SE $(n=4)$.

\begin{tabular}{|c|c|c|c|c|}
\hline Time $[\mathrm{h}]$ & $\begin{array}{l}\mathrm{AAO}\left[\mathrm{Ug}^{-1}\right. \\
\mathrm{H}_{2} \mathrm{O} \\
\text { dark }\end{array}$ & light & $\begin{array}{l}\mathrm{CuSO}_{4} \\
\text { dark }\end{array}$ & light \\
\hline 0 & $3.35 \pm 0.15$ & $3.35 \pm 0.15$ & $3.35 \pm 0.15$ & $3.75 \pm 0.15$ \\
\hline 4 & $2.99 \pm 0.57$ & $5.60 \pm 0.41$ & $4.76 \pm 0.49$ & $7.30 \pm 0.54$ \\
\hline 8 & $3.40 \pm 0.22$ & $6.66 \pm 0.37$ & $3.41 \pm 0.21$ & $10.80 \pm 0.78$ \\
\hline 12 & $3.39 \pm 0.20$ & $8.28 \pm 0.28$ & $9.24 \pm 0.39$ & $14.62 \pm 0.42$ \\
\hline 24 & $4.53 \pm 0.86$ & $11.86 \pm 0.36$ & $14.68 \pm 0.27$ & $16.92 \pm 0.77$ \\
\hline
\end{tabular}

To investigate whether other divalent metals also increase the activities of AAO in detached rice leaves, we tested $\mathrm{Mg}, \mathrm{Zn}, \mathrm{Fe}$, and $\mathrm{Mn}$ (Table 3). Results indicate that, under both irradiance and dark, $\mathrm{Mg}, \mathrm{Zn}, \mathrm{Fe}$, and $\mathrm{Mn}$ did not cause an increase in

Table 3. Effects of various divalent metals on AAO activities in detached rice leaves. AAO activities were determined after $24 \mathrm{~h}$ trearment of metals $(10 \mathrm{mM})$ in the dark or light. Means $\pm \mathrm{SE}$ $(n=4)$.

\begin{tabular}{lrr}
\hline Treatment & \multicolumn{1}{l}{$\begin{array}{l}\text { AAU }[\text { dark g '(t.m.) } \\
\end{array}$} & \multicolumn{1}{l}{ light } \\
\hline $\mathrm{H}_{2} \mathrm{O}$ & $4.00+0.26$ & $11.37+0.55$ \\
$\mathrm{CuSO}_{4}$ & $11.16 \pm 0.76$ & $15.36 \pm 0.86$ \\
$\mathrm{CuCl}_{2}$ & $13.66 \pm 0.79$ & $15.59 \pm 0.46$ \\
$\mathrm{MgSO}_{4}$ & $2.75 \pm 0.43$ & $11.33 \pm 0.36$ \\
$\mathrm{ZnSO}_{4}$ & $2.25 \pm 0.24$ & $4.85 \pm 0.34$ \\
$\mathrm{FeSO}_{4}$ & $1.65 \pm 0.43$ & $2.65 \pm 0.84$ \\
$\mathrm{MnSO}_{4}$ & $1.75 \pm 0.54$ & $9.26 \pm 0.45$ \\
\hline
\end{tabular}


AAO activities in detached rice leaves. In addition, $\mathrm{CuSO}_{4}$ and $\mathrm{CuCl}_{2}$ were equally effective in increasing AAO activity, indicating that it was induced by $\mathrm{Cu}$ rather than by $\mathrm{SO}_{4}{ }^{2-}$ or $\mathrm{Cl}^{-}$

To understand whether the effects of $\mathrm{Cu}^{2 *}$ on $\mathrm{AAO}$ activities are specific for green leaf tissue, the effects of $\mathrm{CuSO}_{4}$ on $\mathrm{AAO}$ activities in shoots and roots of etiolated rice seedlings were also studied. Increasing concentrations of $\mathrm{CuSO}_{4}$ from 10 to $50 \mathrm{mM}$ progressively decreased root growth, however, no reduction of shoot growth was observed. The differential effect of $\mathrm{Cu}$ on root and shoot growth could be explained by the fact that $\mathrm{Cu}$ is accumulated mainly in roots and to a minor extent in shoots (Fernandes and Henrigues 1991). As found in light-grown leaves, $\mathrm{CuSO}_{4}$ was effective in increasing AAO activities in roots of etiolated rice seedlings (Table 4). However, $\mathrm{CuSO}_{4}$ had no significant effect on $\mathrm{\Lambda \Lambda O}$ activities in etiolated shoots (Table 4). This is expected if accumulation of less $\mathrm{Cu}$ in etiolated shoots was taken into consideration.

Table 4. Effects of $\mathrm{CuSO}_{4}$ concentrations on the fresh mass and $\mathrm{AMO}$ activities in etiolated rice seedlings. Seeds were germinated at various $\mathrm{CuSO}_{4}$ concentrations for $5 \mathrm{~d}$ in the dark. Means $\pm \mathrm{SE}$ $(n=4)$

\begin{tabular}{|c|c|c|c|c|}
\hline \multirow{2}{*}{$\mathrm{CuSO}_{4}[\mu \mathrm{M}]$} & \multicolumn{2}{|c|}{ Fresh mass [mg organ $\left.{ }^{-1}\right]$} & \multicolumn{2}{|c|}{$\mathrm{AAO}\left[\mathrm{U} \mathrm{g}^{-1}\right.$ (f.m.)] } \\
\hline & shoot & root & shoot & root \\
\hline 0 & $25.02 \pm 0.42$ & $12.94 \pm 0.57$ & $5.15 \pm 0.15$ & $1.15 \pm 0.25$ \\
\hline 10 & $26.21 \pm 1.30$ & $9.29 \pm 0.40$ & $5.08 \pm 0.14$ & $2.50 \pm 0.30$ \\
\hline 20 & $24.41 \pm 1.00$ & $7.51 \pm 0.20$ & $5.72 \pm 0.24$ & $3.41 \pm 0.17$ \\
\hline 30 & $25.72 \pm 0.50$ & $6.55 \pm 0.21$ & $5.33 \pm 0.39$ & $7.31 \pm 0.39$ \\
\hline 40 & $26.53 \pm 1.20$ & $5.80 \pm 0.14$ & $5.17 \pm 0.10$ & $8.65 \pm 0.17$ \\
\hline 50 & $22.60 \perp 1.30$ & $3.93 \perp 0.45$ & $5.92 \perp 0.36$ & $10.50 \perp 0.52$ \\
\hline
\end{tabular}

\section{Discussion}

Arrigoni et al. (1981) reported that many plant tissues lacked AAO activity. In the present study, we demonstrated that AAO is present in green leaves of rice and roots and shoots of etiolated rice seedlings. AAO activity in rice shoot apices during panicle formation has also been reported (Reddy et al. 1986).

There have been reports that the activities of several enzymes in plant tissue is induced by $\mathrm{Cu}^{2+}$. Bligny et al. (1986) has reported that laccase activity in sycamore cells is increased hy adding $\mathrm{Cu}^{2+}$, which is component of laccase Ikeda et al. (1982) have also reported that cytochrome $a a_{3}$ content in cultured tobacco cells increases after subculturing in higher $\mathrm{Cu}^{2+}$. Delhaize et al. (1986) have reported that the amount of diamine oxidase protein in clover leaves is controlled by the copper concentrations of the leaves. We now report that the increase in AAO activity in detached rice leaves or roots of etiolated rice seedlings treated with $\mathrm{CuSO}_{4}$. Our results are consistent with those of previous work in which $\Lambda \Lambda O$ in cultured cells of fruit tissues was activated by $\mathrm{Cu}^{2+}$ (Esaka et al. 1988a,b, 1992, Sekiya et al. 1990, 
Pitari et al. 1993).

Of particular interest is the finding that $\mathrm{Cu}^{2+}$ is more effective in activating AAO in detached rice leaves in the dark than in the light. This is mainly due to the fact that $\mathrm{AAO}$ activity in detached rice leaves in the absence of $\mathrm{Cu}$ in the dark is much lower than that in the light. We also demonstrated that in the absence of $\mathrm{CuSO}_{4}$ irradiance was effective in increasing AAO activity when compared with dark controls. However, Esaka et al. (1988a) showed that light had no effect on the AAO activity in pumpkin callus. Phytochrome-mediated induction of AAO in mustard seedlings has been reported (Van Poncke ot al 1969, Drumm et al 1972., Acton et al 1974).

Lin and Varner (1991) proposed that AAO may be involved in zucchini cell growth. Esaka et al. (1992) showed that AAO was involved in cell growth or cell division of pumpkin fruits. More recently, Takahama and Oniki (1994) reported that one of the causes of the enhancement of elongation growth by indole-3-acetic acid in epicotyls from Vigna angularis is related to an increase in AAO activity. However, it seems unlikely that the increase in AAO activity is related to root growth of rice seedling, because $\mathrm{Cu}$, which increases AAO activity, reduced root growth of rice seedlings. It is clear that AAO is not universally associated with cell growth in plants and is most likely confined to certain plant species.

\section{References}

Acton, G.J., Drumm, H., Mohr. H.: Control of synthesis de novo of ascorbate oxidase in the mustard seedling (Sinanis alha L .) by phytochrome. - Planta 121: 39-50. 1974.

Arrigoni, O.. Dipicrro, S., Borraccino, G.: Ascorbate frec radical reductase, a key enzyme of the ascorbic acid system. - FEBS Lett. 125: 242-244, 1981.

Bligny, R., Gaillerd, J., Douce, R.: Excretion of laccase by sycamore (Acer pseudoplatanus) cells. B10chem. J. 237: $583-588,1980$.

Cho, H.J., Aimi, T., Paik, S.Y., Murook, Y.: Secretory production of ascorbate oxidase by cultured cells of cucumber. - J. Ferment. Bioeng. 68: 193-199, 1989.

Delhaize, $\Gamma$, Dilworth, M.J., Webb, $\mathbf{I}$ : The effect of enper nutrition and develnpmental state on the biosynthesis of diamine oxidase in clover leaves. - Plant Physiol. 82: 1126-1131, 1986.

Drumm, H., Brunning, K., Mohr, H.: Phytochrome-mediated induction of ascorbate oxidase in different organs of a dicotyledonous seedling (Sinapis alba L.). - Planta 106: 259-267, 1972.

Esaka, M., Imagi, J., Suzuki, K., Kubota, K.: Formation of ascorbate oxidase in cultured pumpkin cells. - Plant Cell Physiol. 29: 231-235, 1988a.

Esaka, M., Uchida, M., Fukui, H., Kubota, K., Suzuki,. K.: Marked increase in ascorbate oxidase protein in pumpkin callus by adding coppcr. - Plant Physiol. 88: 656-660, 1988 b.

Esaka. M., Fukui. H., Suzuki,. K., Kubota, K.: Secretion of ascorbate oxidase by suspensioncultured pumpkin cells. - Phytochemistry 28: 117-119, 1989.

Esaka, M., Suzuki,. K., Kubota, K.: Stimulation of ascorbate oxidase secretion from cultured pumpkin cells by eosin yellowish and potassium salicylate. - Phytochemistry 29: 1547-1549, 1990.

Esaka, M., Fujisawa, K., Goto, M., Kisu, Y.: Regulation of ascorbate oxidase expression in pumpkin by auxin and copper. - Plant Physiol, 100: 231-237, 1992.

Fernandes, J.C., Henriques, F.S.: Biochemical, physiological, and structural effects of excess copper in plants. - Bot. Rev. 57: 246-273, 1991.

Ikeda, T, Matsumnto, T., Ohi, Y.: Influences of copper concentration on cytochrome $a a_{3}$ formation and growth in cultured tobacco cells. - Agr. biol. Chem. 46: 565-566, 1982. 
Kao, C.H.: Senescence of rice leaves. IV. Influence of benzyladenine on chlorophyll degradation. Plant Cell Physiol. 21: 1255-1262, 1980.

Lin, I.-S., Varner, J.-E.: Expression of ascorbic acid oxidase in zucchini squash (Cucurbita pepo L.). - Plant Physiol. 96: 159-165, 1991.

Pitari, G., Chichiricco, G., Marcozzi, G., Rossi, A., Maccarrono, M., Avigliano, L.: Expression of ascorbate oxidase in cultured zucchini cells. Effect of copper and abscisic acid. - Plant Physiol. Biochem. 31: 593-598, 1993.

Reddy, K.P., Khan, P.A., Mohanty, G.B., Kumar, K.B.: Ascorbate oxidase activity in rice shoot apices during panical initiation. - Plant Cell Physiol. 27: 725-728, 1986.

Sckiya, J.. Mizuno, K., Kimura, O., Shimose, N.: Ascorbate oxidase in cucumber calli and enhancement of enzyme activity by copper sulfate. - Soil Sci. Plant. Nutr. 36: 43-51, 1990.

Takahama, U., Oniki, T.: The association of ascorbate and ascorbate oxidase in the apoplast with IAA-enhanced elongation of epicotyls from Vigna angularis. - Plant Cell Physiol. 35: 257-266, 1994

Van Poucke, M., Barthe, F., Mohr, H.: Phytochrome-mediated induction of ascorbic acid oxidase in mustard seedlings. - Naturwissenschaften 56: 417, 1969.

Weis, W.: Ascorbic acid and electron transport. Ann. N. Y. Acad. Sci. 258: 190-200, 1975. 